\title{
Distinctive and comparative places: alternative narratives of distinction within international student mobility
}

Laura Prazeres $^{\star a}$, Allan Findlay ${ }^{\mathrm{a}}$, David McCollumª, Nikola Sanders ${ }^{\mathrm{b}}$, Elizabeth Musil ${ }^{\mathrm{c}}$, Zaiga Krisjane $^{d}$, Elina Apsite-Berina ${ }^{d}$

a Department of Geography and Sustainable Development, University of St Andrews

${ }^{b}$ Department of Demography, University of Groningen

${ }^{c}$ Department of Geography and Regional Research, University of Vienna

d Department of Geography, University of Latvia

* Corresponding author

\begin{abstract}
Moving beyond the 'world-class' institutional model of international student mobility, this paper examines alternative narratives of distinction relating to place of study. Drawing on semistructured interviews with international students at universities in the UK, Austria and Latvia, we illustrate how students inside and outside mainstream reputable higher education institutions narrate and reconfigure markers of distinction to validate their international mobility and location of study, in part to compete with peers at other (more prestigious) institutions. We demonstrate the importance of lifestyle and experiential places within a global differentiated higher education landscape and argue that many students engage in comparative narratives of place of study to authorise the symbolic capital associated with international education. The findings also consider how experiential places and mobility capital are used for distinction not only during educational mobility but within post-study aspirations.
\end{abstract}

\section{Keywords}

Comparative places; international education; international student mobility; distinction; mobility capital; mobility aspiration 


\section{Introduction}

International student numbers are increasing worldwide along with the internationalisation of higher education. World-class universities in particular attract large numbers of applicants hoping to join the 'elite' ranks of higher education and all the benefits that this entails following graduation. In the UK, Oxbridge has long held the mantle of institutional reputability within higher education, casting a shadow on less esteemed but arguably no less respectable institutions. Yet, as this paper will argue, the importance of place should not be overlooked within a global higher education context. While the academic prestige associated with elite universities endows students with professional and personal distinction, other higher education destinations and institutions also offer distinctive qualities that entice prospective applicants. Extending the scope beyond an entirely 'world-class' institutional focus, the aim of our paper is therefore to deepen understanding of claims of distinction that relate to place of international study.

The symbolic struggle between institutions within a globalising higher education market seems to have widened in scope from academic prestige to place distinction (Collins 2014). In comparing the options available to them within a global higher education system, some international students' choice of destination may have just as much to do with the distinction and quality of everyday life as of the formal education on offer (Ho 2014). This study redresses the overlooked importance of lifestyle and experiential pursuits in international student mobility scholarship. With the dominance of institutional reputation and prestige within higher education, the originality of this paper lies in demonstrating that quality of life and place matter. It advances scholarship by illustrating how place of study is integrated into a student's lifecourse and future possibilities. Instead of confining comparisons to the reputation and prestige of institutions, we will argue that students draw comparisons between distinctive places (Raghuram 2013). The paper sheds light on our understanding of narratives of distinction and comparative places within higher education. The importance of place, as we will show, not only lured students to particular destinations, but was also used in narratives of distinction to validate their international study location and to compete with peers in other places. Drawing on semistructured interviews with international students in the UK, Austria and Latvia, the paper offers conceptual and theoretical contributions to alternative narratives of distinction within a differentiated higher education system. We suggest that, given constraints (e.g. finances and failures which might impede access to world-class universities), some students seek out other 
ways to validate and enhance the recognition that might be given to their education and reconfigure distinction through alternative markers.

We illustrate this by reviewing the literature on the motivations and drivers for international mobility in order to build on scholarship that theorises these through distinction. We then present the methods used to unpack the conceptual basis of place within distinctionmaking from students' narratives. Our findings are presented in relation to three themes: first, we examine the importance and comparative framing of 'place' for symbolic capital within international student mobility. Second, we demonstrate how social diversity is drawn upon within these experiential and comparative narratives of distinction. Third, we explore how the importance and symbolic value of experiential places extends well beyond educational experiences to post-study mobility aspirations.

\section{The drivers of international student mobility}

The research literature recognises diverse drivers of international student mobility, mostly derived from theories of human capital (Gérard and Uebelmesser, 2014). The different forms of capital - i.e. economic, cultural, social, and symbolic - are resources that can be converted and exchanged for financial and social gains. International education is seen to provide valuable and varied accumulations of cultural and social capital that can be used towards economic capital within future employment (Holloway et al., 2012; Waters 2005). Much of the work on student motivations for overseas study has explained their mobility in terms of improving job opportunities following graduation (Baláz and Williams, 2004; Brooks and Waters 2009a). Waters (2006) has shown how family units temporarily relocate abroad for higher education as part of a family strategy to gain cultural capital that can benefit students' future credentials. Indeed, for some international students, familial and social networks are the driving forces behind their educational mobility. The study abroad experiences of friends and wider social networks can support and inform students' decision to move overseas (Beech 2015) while for other students the presence of social ties and co-nationals (Ma 2014) or romantic partners (Brooks and Waters 2010) living abroad guided their mobility to specific destinations. Overseas studies are also a way for students to build social contacts as future resources for the workforce, but also to acquire social capital to gain entry into an exclusive and distinctive group.

As cultural and social capital is primarily and prevalently accumulated within international student mobility, it inevitably endows students with an advantage over peers in the labour market (King et al. 2011; Waters 2012) but also with a social mark of distinction (Findlay et al. 
2012). Symbolic capital - a component of cultural capital recognised through prestige - can derive from the recognition of uniqueness and difference in social and institutional standings. World university rankings have become the barometer for institutional reputability and prestige and, by that effect, the measure of social distinction of its students. Among a cohort of UK students overseas, Findlay et al. (2012) found that students sought difference and distinction by attending a 'world-class' university. Since these institutions exemplified academic and social prestige through their highly rated reputation within global higher education rankings, students were able to draw more than just academic credentials from their studies overseas; they distinguished themselves from peers in the UK through their newly acquired and enhanced symbolic capital. This indeed reinforces pre-existing inequalities and differences between young people in the country of origin by positioning already privileged students (those with prior human capital) ahead of stay-at-home peers (those deprived of the necessary human capital for mobility). However, with many world-class institutions located in the UK, British students' mobility to other reputable institutions overseas may indicate a less direct path towards distinction. In fact, for British students denied access to 'elite' institutions at home, such a move overseas can reflect what Brooks and Waters (2009b) have termed as a 'second chance' opportunity for achieving 'success'. An international education at ivy leagues or other foreign 'elite' universities becomes a 'roundabout route' to obtain valuable forms of cultural and social capital for distinction upon return home (Waters 2006). However, much less is understood of international students at institutions on the margins of the prestige spectrum. Our study thus investigates the experience of international students not only in the UK, but also in Austria and Latvia.

Implicit in students' pursuit of prestige in international studies are their prior experiences of mobility which facilitate and even drive their educational moves beyond national borders (Carlson 2013). In this sense, mobility capital - based on previous mobility experiences and indirectly through those of the family (Murphy-Lejeune, 2002) - is sought and reproduced through international educational mobility and can be drawn on for professional or personal ambitions later in the lifecourse (Findlay et al. 2006). Brooks and Waters (2010) have argued that mobility capital is entwined with the other forms of human capital and that young people may be embedded in a (generational) culture that regards international travel as a valuable experience. Indeed, King et al. $(2011,164)$ have attributed part of students' international studies to a 'youth mobility culture' in which living and travelling abroad are a 'rite of passage', and Findlay et al. $(2012,124)$ echo this perspective by noting 'the social construction of "internationality" within this educational milieu'. Although prior mobility can incite future mobility 
for an international career (Findlay et al., 2016), post-study trajectories are largely constrained by students' social networks (Geddie, 2013). In fact, recent studies point to students' post-study aspirations as emergent and influenced by social networks, both in their place of origin and their current place of study (Collins et al., 2016; Mosneaga and Winther, 2013). Nevertheless, research in this area still has gains to make in understanding how mobility capital is utilised during and after international studies. As such, this paper considers the intended use of mobility capital within post-study distinction and lifestyle aspirations.

With these summative findings, scholars have contributed to theorising international student mobility through a search for educational prestige and hence distinction. However, educational desires for symbolic capital and mobility are not necessarily calculated in advance but are instead emergent and fluid in relation to previous experiences, future aspirations and social relationships (Collins et al., 2014; Yang, 2016). In contrast to international studies as a strategy for future employment, scholars have found that some students seek out or gain cultural and mobility capital within experiential, rather than professional goals (Findlay et al. 2006; Waters et al. 2011). For example, Waters et al. (2011) have revealed that for some British students a degree abroad represented an opportunity for fun and adventure. Instead of viewing overseas study as a strategic measure to advance and compete within the labour market, students' motivations were driven by a search for happiness which nevertheless entailed the accumulation of cultural and symbolic capital. Privilege and advantage can be reproduced, even unintentionally, through a pursuit of adventure and a 'carefree student lifestyle' (Brooks and Waters 2010, p. 217). Building on these works, the paper will show that the production of distinction within more experiential inclinations is fluid and emergent but very much intentional once at the place of study. Indeed, in the case of lifestyle migrants, Benson and O'Reilly (2009) suggest that the levels of symbolic capital that these privileged migrants carry prior to their move overseas will determine not only their choice of location but also their choice of lifestyle in that place. In other words, international migrants with lower quantities of cultural and social capital may seek to engage in a culturally and socially diverse lifestyle that would enhance their cosmopolitan capital. In this sense, lifestyle choices can also influence an accumulation of symbolic capital and hence, distinction.

Although international students may have contrasting motivations for studying overseas (i.e. professional and/or experiential goals) it would seem the outcomes of their experiences yield the same result - distinction. As such, in illustrating students' search for difference and happiness in international education, scholars have raised the importance of experiential and lifestyle pursuits often overlooked within the student mobility literature. We therefore take these 
pursuits as the starting point in our search to deepen understanding of the relation between place of study and distinction.

\section{Place and distinction}

The imaginations and importance of place are enmeshed with specific lifestyle desires. Although the lifestyle pursuits of long-term travellers has generated a growing body of literature within migration studies (Benson and O'Reilly, 2009; Cohen et al. 2015), it has not received the same attention within international student mobility. Yet, as noted earlier, some scholars are extending these perspectives to international students. With Waters and Brooks' (2011) highlighting the pursuit of adventure and a relaxed student lifestyle as motivations for educational mobility, Brooks et al. (2012) have followed suit by pointing out 'the appeal of alternative ways of life and different cultural values' for international students (p. 293). Indeed, international students consider opportunities for leisure and lively cultural settings on an equal footing with that of a quality education, and the availability and accessibility of amenities within an urban centre can indicate the potential of a place to offer a desired lifestyle (Ho 2014). Conversely, Soon (2012) found that the lifestyle in the country of origin is also a factor in international students' decisionmaking on whether to stay in the host country or return home following their studies. Quality of life and specific ways of living can therefore be an impetus for international migration and, as this study will show, specifically for international student mobility. Yet, desires for a certain way of life can evoke geographical imaginations as particular places are often associated with specific lifestyles.

In their search for a better way of life, Benson and O'Reilly (2009) have argued that lifestyle migrants relocate to particular destinations that correspond to their personal imaginaries. Similarly, in their studies of international students, Collins et al. (2014) highlighted the role of popular culture, media and social circles in fashioning imaginative geographies of mobility, while Beech (2014) has shown how imaginative geographies of place influenced students' decision-making process and locational study choices. International students impress their lifestyle desires onto their place of study in a way that reifies these imaginations for comparisons (Collins 2014; Raghuram 2013). Places are seen to offer different qualities and various ways of living and are therefore compared on the basis of these imaginations. Indeed, Benson and O'Reilly (2009) have argued that the pursuit of a desired lifestyle is part of a 'comparative project'. From a student migration perspective, Raghuram (2013) has pointed out that, while most research on international student mobility remains framed by the nation state, 
international students tend to draw their comparisons between places. These comparisons become the drivers for international student mobility as the attributes and shortcomings of one place are evaluated and weighed against those of other places. Discrepancies between places and their resulting mismatches with students' desires therefore incite mobility towards the more relevant destination within a global comparative landscape. Comparisons between places here are not only based on the lifestyle 'fit' but on the perception that places are 'marked by individuality and distinction' (Raghuram, 2013, p. 143).

Much as institutions are differentiated based on reputation, places are also hierarchized according to their desirability and distinctiveness (Raghuram 2013). Places carry reputations which can make them stand out favourably or adversely within an everyday context but also a higher education contest as institutions vie for greater quantities and quality of student applicants. Biao and Shen (2009) have pointed out that countries and cities are differentially ordered within an academic reputability hierarchy, with countries such as the US and the UK positioned at the top tier while other countries descend lower in the ranks. Cities such as London (Tindal et al. 2015) and Seoul (Collins 2014) also hold reputations and distinctions within their regions for (inter)national study. Yet, these symbolic rankings tend to originate from historical and mainstream (Western) conventions which maintain a hegemonic stance over emerging and peripheral higher education regions. Thus, stakeholders and institutions particularly those located in less academically renowned places - will play up the distinctive qualities of their location to attract prospective students. Indeed, study places market themselves against the symbolic qualities of other places within a global differentiated higher education landscape (Collins, 2014). For example, through a desire to achieve a 'world-class' status, cities in Asia will promote the 'worthiness of a place' by combining Western markers of quality education with Eastern values and lifestyles through the 'East meets West' discourse (Phan 2016, p. 57). Place therefore matters in terms of lifestyle and educational opportunities for attracting international students to specific cities (Shen 2010). Although perceptions of the 'best' places to study will vary according to different regional perspectives, it demonstrates the symbolic currency and capacity of place to negotiate distinction alongside and - as this paper will show - potentially above institutional prestige. Students can therefore compete for symbolic capital and distinguish themselves from peers through their place of study (Tindal et al. 2015). Before illustrating this thread of distinctive and comparative places through empirical data, the next section will present the methodology used to capture the significance of place and the underpinnings of distinction within students' narratives. 


\section{Methodology}

This paper reports work from a larger project on international student mobility within Europe. The overall objective of the wider project was to answer the question 'How is the production of international student migration best explained?' The framing of this question reveals our ontological position that international student destinations cannot be explained only as a function of individual choices, but involves much deeper seated social, economic and cultural forces (Collins and Shubin 2015; Collins et al. 2016). While evidence gathered from speaking with international students may reveal their personal motivations and individual decisions, student migrants need to be understood in much more complex relational ways that captures both their situatedness and the holistic nature of student mobility as part of lifecourse mobilities (Findlay et al. 2016). This implies that the spatio-temporal variation evident in researching international student destinations cannot be adequately understood from adopting what might be termed individualistic methodologies to explain behavioural outcomes, but rather requires the elicitation of the socio-cultural forces shaping the value sets that produce the meanings associated not only with international study but also the places of study (Raghuram, 2013).

The wider research programme included an online survey of nearly 4000 international students studying in three European countries and in-depth interviews with international students and key stakeholders from university international offices, as well as other actors such as educational agencies like the UK's British Council. This paper draws only on the in-depth interviews with students, since this was judged the richest comparable source of information about the signifiers attaching to selection of place of study. Students were recruited through their participation in the survey and volunteered their time for the interviews. Semi-structured international student interviews lasted on average 40 minutes and were conducted in situ and face to face with international students in the UK (31), Austria (21) and Latvia (12) between April and November 2015. The interview themes covered students' motivations for international study, previous educational experiences, family and social networks, and post-study aspirations.

The annual OECD (2016) comparison of educational provision and attainment across OECD countries, shows very clearly that UK and Austria are consistently ranked very highly in terms of the number of foreign students as a percentage of total of all enrolments in tertiary education ( $3^{\text {rd }}$ and $5^{\text {th }}$ respectively in the world, and $2^{\text {nd }}$ and $4^{\text {th }}$ in the EU, as shown in Figure 1). International student recruitment therefore stands out as very important to the higher education sectors of these two countries. Both record $17 \%$ of all enrolments in the most recent year for which comparative data is available behind Luxembourg with $44 \%$ of its tertiary student 
enrolment made up of foreigners. We chose not to undertake research in Luxembourg since it is rather a unique case in terms of the state's approach to higher education provision, which involves the out-migration of very large numbers of its own young people for study elsewhere. It was decided however to include a third comparator country within the EU to provide insights of the imaginaries of study locations in Eastern Europe. Latvia, with $4 \%$ of its higher education enrolment accounted for by foreign students has the highest proportion of any of the Baltic republics. It was also selected because it recently adopted a new strategy to promote itself as a desirable destination for international study (Ministry for Education and Science, 2016). Our final selection of three study locations therefore reflected a West, Central and East European country from within the EU.

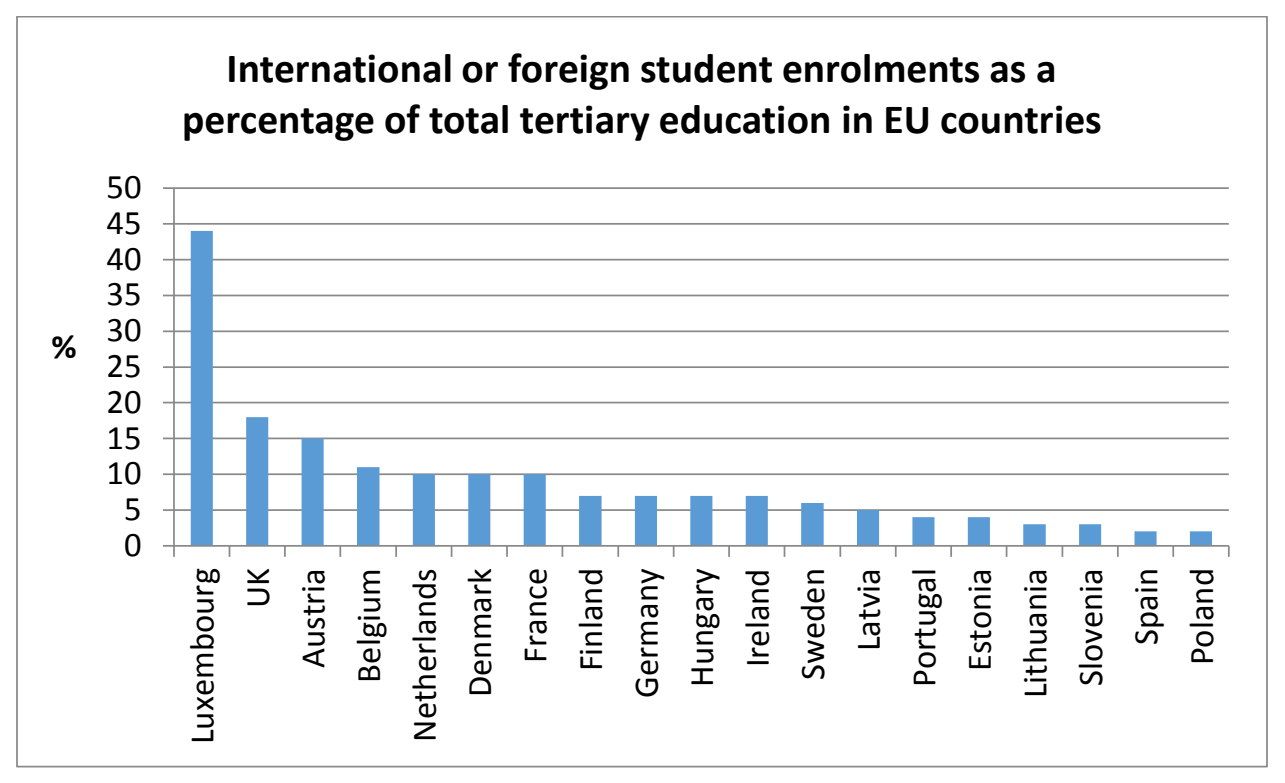

Figure 1. International or foreign student enrolments as a percentage of total tertiary education in EU countries. Source data: OECD Table C4.1 http://www.oecd.org/education/skills-beyond-school/educationat-a-glance-2016-indicators.htm

In each country international students were recruited on the criteria of degree-mobility; that is, they were enrolled in a university in the UK, Austria or Latvia for the entirety of a degree program. Our sample consisted of both undergraduate and postgraduate students. Although we tried to recruit students from a breadth of universities within these countries, the majority of students in Austria who took part in the interviews were studying in Vienna, while those in Latvia were mostly in Riga. The UK sample drew a more varied representation of institutions across 
the different regions. International students themselves came from a variety of countries (30) inside and outside of the European Union.

While we aimed for a diversity of receiving universities and sender countries we cannot claim a representative sample of international students in terms of our in-depth interviews, nor do we wish to generalise our findings to represent the three countries in any statistical sense. Instead, we sought to illuminate the meanings produced through international student mobility from and to different countries. Interviews were transcribed verbatim and the transcripts were read and re-read with emerging themes coded and then merged to form larger categories. This iterative process produced three main thematic categories as the following substantive sections of this paper will illustrate. All participants were given pseudonyms, with tag of quotations in the text only identifying geographical descriptors, with most other interviewee traits suppressed to maintain confidentiality.

\section{The lure and allure of place}

The appeal of place is one of the main motivations that lures students to particular cities rather than specific institutions (Ho 2014). Particular places and the particularities of these places can offer desirable opportunities and amenities that appeal to students' everyday lifestyle aspirations. The value and prestige of reputable universities are thus weighed against students' more mundane and extra-curricular interests. The following student voices show how places are inscribed into a comparative process whereby the everyday attributes of a location are not only evaluated vis-à-vis institutional worth (i.e. tuition cost and prestige), but also compared to those of other locations. In a study of international students in Malaysia, Singh et al. (2014) have found that the destination and location of study preceded and guided the choice of institution. From this perspective, places become the main drivers for mobility while institutional reputability takes a backseat. Having moved from Bolivia to study in Vienna, Claudia explains that,

Maybe I could have gone to a little town with a great university in Germany, but it wouldn't have been the same because the city has something else to offer.

When asked if the cost of studying in Austria factored in her decision, she replied:

I think it would have been cheaper [in Germany], but it was the quality of life. 
Claudia demonstrates how institutional greatness and fee differentials were negligible in comparison to the urban appeal of Vienna. Notably, the quality of life was prominently articulated by students as essential to their international studies, highlighting the underestimated importance of leisure and well-being within international student migration (Waters et al. 2011). It is the Viennese lifestyle that suits Claudia's everyday needs. Place therefore matters, but not necessarily for curricular reasons. Manuel, a Spanish student in Riga, explains how the capital of Latvia was important for his location of study:

The point of living in Riga, capital city, is important for me. ... For me it's really important that I can make social life. ... I have some places to go to chill with my friends, to have a drink with some kind of good environment, music. ... So for me, that's one of the most important things here; that you have wide spectrum of different places where to go and enjoy your free time.

Manuel indicates that the variety of locales offered by a capital city provide opportunities for developing and enjoying a socially active and diverse lifestyle. Places are not just compared or distinctively marked by particular amenities and features, but by the diversity of these recreational amenities within a social landscape. Much like Claudia, the importance of place above that of the institution was shared by Hannah, a Finnish student in Vienna:

I sort of came to Vienna just because of the city, or more because of the city... there are better universities that would have suited me better.

For Claudia, Manuel and Hannah, the urban locality of their studies eclipsed academic reputation. The value of place itself is contrasted to and favoured above institutional imperatives, revealing international students' more everyday place-based sensibilities. While particular place-based lifestyles and urban amenities seem to matter more than financial and academic factors, these narratives may alternatively reveal students' insecurities over their (less academically prestigious) location of study within a dominant institutional and hierarchical global higher education market. As such, it could be that some students attempt to compensate for lower institutional prestige by shifting the focus and emphasis on place-based markers in order to generate symbolic capital. Participants frequently, if not consistently, compared their location of study with other places or (more academically favourable) universities. More specifically, comparisons were not drawn between institutions but rather between places. These 
comparisons are not incidental; they are statements that acknowledge institutional prestige but they challenge assumptions of its overriding prominence. In other words, students recognize the differential (and greater) worth of specific universities within a symbolic global hierarchy system but some students attempt to counter claims of institutional predominance by contending that the location of study outweighs institutional desirabilities. Instead, amenities such as public transportation and entertainment epitomized the qualities sought from of a place of study and superseded institutional worth. Hannah elaborates further:

I'm really glad that I came to Vienna because the city is fantastic. Just in free time I think that you have more things to do, especially in summer you have all of these free activities and festivals. At Rathaus plaza there is always something happening... the free cinemas and so on. (Hannah)

Many of our interviewees emphasised the importance of everyday lived experience in the city, whilst references to the academic experience were conspicuously absent from the narratives. Institutional prestige and academic reputation were overshadowed by the distinctive experiential qualities of study places.

Particular cities seemed to hold more value or, as Emre from Turkey suggests, more distinctiveness:

Vienna is like super, everything is in order, you know, and everything works super efficiently. You know, metros come on time, there is public connection for everything; there are night buses you know. And then there is perfect insurance. You can go to the doctor and don't have to wait for one day until you can go and see the doctor. What really impressed me was the high quality of living in Vienna. As you know, it has been selected, I think four times in a year now (as) the best city to live in the world, in a row.

While listing the enumerable and desirable features of its urban centre, Emre is (not-socasually) underlining the long-standing ranking of Vienna as the 'best' city in the world. This seems a way to highlight the distinctive quality of the city as a location of study and by this measure, he points to the cultural and symbolic capital that he personally is accruing (Tindal et al. 2015). Thus, rather than subscribing to dominant processes of institutional ranking of worldclass universities for symbolic value, some of our interviewees engaged in comparative rankings of international cities as alternative narratives of distinction. Places then are compared 
and showcased on a highly competitive and stratified global higher education scene in order to compete for symbolic distinction. The same type of account was found in our interviews in London. Suzanne, a Canadian PhD student, explained why after being accepted both by a London college and a Welsh university, she elected to study in London:

London (University X) seemed like a really good fit and London was definitely a city I wanted to live in. And I think some of it had to do with the program and, you know, courses and supervision, but some of it definitely had to do with lifestyle and the fact that I couldn't necessarily see myself living in (Welsh University town) for four years.

Rather than focus on the reputation of her London college over the Welsh University, Suzanne points to the urban lifestyle of her study location as the distinctive feature for her destination choice. Urban centres are linked to specific material and social features and evoke a particular way of life (Collins 2014). Yet, Suzanne does not showcase London by explicitly enumerating a series of amenities but rather, the importance of an urban space is elicited through a comparison with a relatively more rural place. Indeed, students draw their comparisons between places such that 'the vectors of difference between 'here' and 'there' become the causative factors for migration, and the differences between places are summarised by the hyphen as in rural-urban' (Raghuram 2013, p. 143). The image of places like London and Vienna as international cities conjures up distinctive qualities that students wish to tap into as part of a sought out international educational experience. Place therefore imparts additional or greater (symbolic) value to students' international education.

The uniqueness and distinctiveness of particular places was also evinced through their imagined association with particular mindsets. For instance, a German studying in Vienna said she 'liked the philosophy' of the city, while David, an American who has lived in almost 30 different cities in the US, reflected on the global outlook of Vienna that differed from his country of origin:

In general I find my world view and value system is compatible here. And that is something that sort of drove me out of the States. ... I found myself not having the same value system, I felt alienated in my own country. Here I am clearly an alien in a much more direct way, but in a more superficial way with language or cultural background and things, but on a deeper level I feel much more 'at home'. 
Despite evident linguistic and cultural differences, David feels that the local Viennese values are compatible with his personal views in a way that not only evoked a unique sense of place, but attested to a successful local immersion that endowed cultural capital. By describing a stronger sense of belonging and portraying Vienna as 'home', he validated his international mobility and projected a meaningful educational experience. However, the meaningfulness of his experience is rendered most effective and compelling by contrasting the compatibility and sense of belonging of his new 'home' place with the unsettled and conflicting feelings produced in his previous 'home' in the US. International students thus inscribe places into a comparative framework and experiential higher education landscape. As Raghuram (2013) points out, 'comparisons are never neutral; they hierarchise places along particular axes' (p. 144). Indeed, comparisons become an effective narrative device to tease out the differences between places and, in doing so, highlight the differential value of 'place' for students' experiential and symbolic capital acquisition. The next section develops the importance of international and social diversity as a means of showcasing and comparing places of study.

\section{International diversity and social networks}

Social networks and the internationality of place was a second theme to emerge from our interviews. Places of study were described as constantly in motion in relation to a wider (global) network of places and study destinations. The fluidity of social networks attested to how places were understood as relational and this contributed to how participants differentiated places of study. Continuing the conversation with David, he compares his former experience in the USA with the social diversity offered by Vienna:

I rarely found myself (in the US) surrounded by difference, whatever that is...... I didn't often encounter it in daily life. That allowed me to develop a lot of ideas that may not be right without any sort of critical resistance. To study abroad was really great ... because of the diversity of the students of the different faculty... It feels to me there's something about just being exposed to different ways of living and different ages and diversity in general that if you are thoughtful it encourages you to be a bit more moderate where moderation is wise. ... It's a stronger filter for how you see the world and developing your own kind of world view. 
Difference and diversity interchange synonymously within David's comparative narrative of places as though the repetition of these terms is meant to both reinforce the value of difference in Vienna as well as Vienna's difference from the United-States. In other words, diversity and difference within a place is not only valued by international students but also used to differentiate and distinguish their place of study from other places (Waters and Brooks 2011). Thus, it seems that the apparent 'greater' social diversity of these places overshadows institutional reputation (or the lack thereof). Satish, an Indian student in Riga, also points out the international diversity of the social relationships he has developed so far during his studies in Latvia:

I met new friends here, and Latvian friends, you know, Uzbekistan friends, everyone. That's why I'm enjoying it. With other country people I'm learning other country people's way of behaviour and culture.

Satish not only mentions newly acquired friendships, but specifically that these are local Latvians as well as international friends. International students often acknowledge the difficulty in developing friendships with local citizens. Thus, unlike students that struggle to befriend locals in their place of study, Satish points to his successful integration within Latvian social circles in a way which signals distinction. Through new friendships with local and international students, Satish highlights that he has diversified his social and cultural repertoire and gained some intercultural competencies which can be converted into cultural and symbolic capital. Similarly, Ricardo (a student from Venezuela in the UK) proudly states that his 'community is very much international; I barely use my own language here'. Ricardo indicates that he has succeeded at integrating into a more different and diverse social network rather than remain within the confines of a primarily Spanish-speaking group. Students are likely aware of the stereotype of international students sticking within their own national group and are keen to differentiate themselves from others who do through the social opportunities offered in their place of study. Li, a Chinese student in Vienna, illustrates this perspective:

So far I think my experience is a little bit different from my Chinese fellows. Because some friends like my ex-classmates they told me that they study in UK or America, they told me that life study abroad is not as fun as you imagine. They don't have friends and they don't make friends with new and you can only stay in your own Chinese circle... but 
when I come here it was totally different. I got a lot of friends and I didn't have a Chinese circle. Like, I didn't stay in my Chinese circle.

Li suggestively frames her experience in Austria as more successful than her peers in more academically reputable countries (i.e. US and UK) through the social networks and capital she has gained in Vienna. She even differentiates herself further from her peers by highlighting the international - as opposed to co-national - friendships she has developed in Vienna. These are tactful narratives used to compete with the experience of peers in more prestigious places of higher education. Difference is articulated as a positive and distinctive marker, even if - as Waters and Brooks (2011) point out - students tend to socialise within limited and exclusive international student groups. They argue that these groups may be internationally diverse, but there is little in the way of social diversity. Symbolic capital here is generated from the internationally diverse constitution of the social network, rather than social difference within the group. Places are therefore distinguished and differentiated based on social and experiential opportunities within a local but also international landscape. These social experiences in situ are associated with cosmopolitan qualities (Rizvi 2005) as Li further demonstrates:

I feel like I have world citizenship, you know. I feel easy to adapt to everywhere I went.

This cosmopolitan appropriation through her international networks and education is a marker of distinction that $\mathrm{Li}$ intends to use in her professional and personal pursuits (Tindal et al. 2015). Places are valued and evaluated for the presence of strategic social contacts that can later be used towards seeking entrance into the job market. Mei, a Chinese student, explains how London is an important hub for connecting with individuals in her field of work and was therefore a strategic choice for the future:

To be honest, when I considered my offer London is a really important issue... location and connections with industry may be really, really important. So I prefer if I have chances I just live here.

The opportunities for developing professional connections in a particular city can attract students who are aware that a degree alone may not suffice to secure a job post-study, particularly for employment abroad. Oleg, an Estonian studying in Riga, also attests to the importance of place-based contacts for his career development: 
I obtained contacts; I obtained understanding and ... now I have an international degree, thus it would help me on international level in case I would like to find job opportunity in other country.

Oleg validates and distinguishes his international education in Riga by highlighting the social capital developed in the city. Comparisons among places and markers of distinction are therefore drawn and situated along not only an urban-rural axis but also a spectrum of greaterlesser international diversity and social opportunities. It is the presence but perhaps also transience of contacts that make particular places more attractive and distinctive than others. Places are in a constant state of motion; they are interconnected through the movement of people and the connections between people in different places sustain social networks and linkages between these places. Since large capital cities are characterised by a diverse and continuous flux of social actors, this fluidity contributes to maintaining comparative processes and tensions within a global higher education landscape. The location of study can then offer a gateway to acquiring contacts that are beneficial in pursuit of a career abroad and an international mobile lifestyle. As international friends and social contacts in the host city return 'home' or move to different places following their studies, students' social network expands geographically across space. Thus, as Oleg suggests, students can benefit and draw resources from a geographically dispersed network of social contacts for international job opportunities later in the life course. The next section explores students' post-study mobility aspirations for experiential places.

\section{Future possibilities: mobility aspirations for international places}

The possibility to engage in international mobility post-study was an aspiration repeated by international students in Austria, Latvia and the UK. Students envisioned a career that intersected with aspirations for international travel. Ana, a Russian studying in Vienna, demonstrates this:

My dream is to travel, that my job will connect with travel abroad. ... I hope my job will connect with different countries. ... I want to see the world. This was also one of the points. 
Ana indicates that one of her motivations for an international education was to combine her desires for travel with educational and professional pursuits. The 'point' that she makes is that these life stages - education and then employment - are embedded and situated in a wider lifetime aspiration for mobility and experiential places. Ana's motivations for higher education and employment are thus inseparable from her longer-term mobility aspirations. Instead of an immediate return or an intention to stay in their country of study, many students look towards urban centres in other countries as prospective and favourable places to live and work. For instance, Hannah says that:

I would like to live for example in Copenhagen or maybe Hamburg. Those are cities that are on my list, ... I'm actually looking for jobs right now. I've noticed that I look for jobs that have international possibilities.

While contemplating international employment opportunities, Hannah names some of the cities she hopes to live in following her studies in Vienna. Yet, rather than identify these cities based on the employment opportunities available there, she is considering an international career because of the desire to live in these specific places. Just as institutions of study were secondary to location for students' educational mobility, so too are employers for their poststudy mobility aspirations. In this sense, the experiential qualities of places are also the pivot of future mobility and career aspirations. For others, a plethora of countries rather than specific cities has already been identified as sites of future mobility as Manuel in Riga describes:

I mean, I'm not going to try any other of these Lithuania, Estonia or Latvia [countries], because l've already experienced it and it is quite okay for studying, but I don't see myself in the future, next years, here. ... My idea is to go maybe to Sweden, Finland, Norway; Switzerland is also one of the ideas or maybe Belgium, and in other cases also Canada is one of the ideas as well. Australia is also quite good idea and the Emirates...

As the conversation and list of countries lengthens, Manuel demonstrates how his post-study aspirations are cast across the globe. In detailing the list of prospective countries he is considering, he purposefully excludes Baltic countries from future possibilities due to their perceived relative cultural and/or geographical proximity to Latvia. Simply by being in Latvia, Manuel feels that he has sampled the culture of the region and is perhaps eager to diversify his cultural capital as well as accumulate further mobility capital. By mentioning that Latvia is 'okay 
for studying' but does not fit into his future aspirations, Manuel indicates that different places will appeal to individuals at differing stages in the life course. Since students ascribe different meanings to mobility and place throughout the lifecourse (Cuba and Hummon 1993), particular places may offer amenities suited to a student-friendly lifestyle while other places present qualities that may favour a young professional's way of life. More importantly, participants' poststudy aspirations are characterised by a continuous international mobility as illustrated here by Sandra, a German in Vienna, and Claudia:

I don't think I will stay in any place longer than 6 years (laughs). I think when I'm done with my studies, like even though I like Vienna a lot and I got to know the city.... I want to try something new. (Sandra)

I would like to go somewhere I haven't been before; maybe outside of Europe. (Claudia)

These extracts show how students envision future mobility trajectories based on novelty and future possibilities. Students' longer-term mobility aspirations are driven not necessarily by career ambitions as much as by lifestyle aspirations (Brooks et al. 2012). Their aspirations are therefore part of an ongoing mobile search for newness within global places. Students are not necessarily moving to a different location, but rather for a new place. This corresponds with earlier motivations about the lifestyle and sense of place that incited students to select particular cities for their studies. The experiential qualities of place are thus valued not only within educational mobility but also within broader lifetime mobility. Yet, students' mobility aspirations for novel places remain underpinned by uncertainty and thus, are framed as future possibilities. This desire to remain internationally mobile and live in new places can originate from an international upbringing (Carlson 2013) in which some students are already well-endowed with, and well aware of, prior mobility capital as Claudia recognizes:

I do want to move to other places that I haven't been before because of the way I was brought up.

Childhood and family experiences of mobility can therefore generate further mobility that extends well beyond international studies. Mobility capital is therefore reproduced throughout the lifecourse (Findlay et al. 2006), and while it is accumulated through travel and mobility experiences, it is also enhanced and diversified through multiple international places and 
residencies. Similarly, by accumulating different experiential places, students equally enhance and diversify their cultural capital.

Moreover, this accumulation and diversification of mobility capital and cultural capital is used in narratives (and images) of distinction. For instance, Shayna - an American studying in Belfast - describes how her personal and publicly narrated aspirations for international mobility have generated attention from friends and peers in the United-States:

I think I really expect more from myself and I don't - that sounds judgy - I'm not judging other people's lives to travel or whatever, but I see, ... I've expected myself to go abroad and not just run back home to what I know every time, ... I also think that other people do expect it of me. I don't feel forced into it but they do, like, they look on, because now you have like a public persona on Facebook and social media and they are always looking to see like what are you doing now and like, 'oh you're so crazy, you're always going all over the place!'

Having projected this international image through social media and conversations with friends, Shayna feels a desire to 'live up' and uphold to the expectations of an international lifestyle that has been - deliberately or unintentionally - generated by herself. This propagates a particular image and 'an imaginative geography of life as an international student' (Beech, 2015, p. 344) to peers and friends in the home country that signals a form of distinction. This further demonstrates how place is valued not only for educational mobility and experiences but also long-term mobility as a lifestyle. As such, mobility capital is not only accrued during international studies but, as we suggest, might extend post-study as an ongoing form of symbolic capital accumulation and hence, distinction.

\section{Conclusion}

This paper examined the distinctive mobilities and geographies of international students in the UK, Austria and Latvia. Moving beyond the 'world-class' institution model within global higher education (Findlay et al, 2012), we argue for the importance of 'place' within international student mobility. We have showed that urban (and at times rural) features of places were valued and prioritised by many international students above institutional prestige. The amenities and quality of life offered in specific cities were prominent features that dominated students' narratives and effectively overshadowed academic and institutional reputability. This is 
significant as scholars have noted that the importance of quality of life in international student motivations is often overlooked or downplayed in contrast to institutional or professional imperatives (Raghuram 2013). We argue that although - or even because - the 'world-class' distinction model is not universal, international students engage in comparative places as alternative narratives of distinction. From this perspective, comparisons were not delineated between elite universities, but between places and, between place itself and institutions on a global scale. Our paper therefore does not lead to the conclusion that other researchers adopt a cookbook approach by taking the conventional 'world class' model of student mobility and stirring in the 'place' ingredient. Instead we have argued that alternative narratives of 'comparative places' are fundamental to interpretations of student mobility and that this is especially true when student migration is 'placed' in the context of lifetime mobility aspirations.

Notably, students highlighted urban lifestyle and amenities as distinctive features of their international educational experience rather than institutional reputation. Students compared and hierarchized study places - particularly international cities - on a global social and experiential landscape. Yet, despite the prevalence of urban centres in our sample some international students also expressed the unique and attractive qualities of rural study places. In these cases, the uniqueness of rural places was distinguished from the mass popularity of urban destinations. Importantly, our study reveals the underrated importance of lifestyle within international student mobility, not only as a motivation for international study but equally - or perhaps even instead - as a marker of distinction. In other words, while place is valued above institutional reputability and is used in narratives of distinction, we suggest that this is potentially either to add to existing symbolic capital or instead, a tactic to compensate for lower institutional prestige.

The paper has demonstrated how places are showcased in terms of their international and social diversity. Students' highlighted the international diversity of their social networks in comparison to their home places as well as to other academically prestigious places. This was a way to seemingly validate their international location of study and assert their (greater) cosmopolitan status. While social difference and diversity was evidenced in relative terms, it did attest to the pervasiveness of comparisons in student narratives. Places were inscribed into a global comparative framework and these comparisons created and maintained tensions that (re)ordered places within a competitive and differentiated symbolic higher education market. We argue that these comparative narratives of place of study are strategically deployed to compete with the experience of international students in more academically reputable locations of study to achieve greater gains in symbolic capital. We further suggest that a significant proportion of 
international students attempt to shift markers of distinction away from academic prestige in favour of place-based experiential features.

This paper has therefore aimed to shift broader narratives of distinction within the research literature in a way that valorizes alternative student constructions of the experiences of study in places with less-highly esteemed institutions and in more peripheral places within the higher education landscape. It seems probable within an increasingly competitive and stratified global higher education landscape, that the role of place will be promoted more strongly within narratives of educational distinction in response to at least two forces. The first driver of this trend is the ever-rising proportion of international students that do not gain access to study in the top ranked institutions due to the limited study places on offer in the Oxfords, Yales and Harvards of the educational world. The second driver is the power of marketization, incentivizing universities and states to find new ways of valorising their educational opportunities to the lucrative international student market (Findlay, 2011).

Moreover, we have demonstrated how the experiential attributes of place are valued not only for educational mobility, but also in relation to long-term mobility aspirations. Our paper showed that the place dimension of students' lifetime mobility aspirations underpinned their international career plans. Instead of a strategy to improve employment prospects per se - as is the dominant perspective in the literature - we argue that many students pursue an international education because of lifetime and lifestyle mobility aspirations either to live and work in specific places or certain kinds of places, such as global cities. In other words, post-study mobility aspirations reflect pre-study motivations for experiential places as re-shaped (and sometimes initiated) through the experience of study abroad (Findlay et al. 2016). Much as lifestyle, social network and place-based qualities may have influenced students' choice of place of education, the paper has also revealed that the underlying motivation for a career abroad is often the desire to live in particular places rather than to work for a specific organisation. In this sense, students move for, rather than to, a place. This means that, as students ascribe different meanings and preferences to places over time, their mobile trajectories and geographies will fluctuate throughout the lifecourse according to changing place-based desires. Prospective places were considered for their novelty in relation to students' history of geographical mobility. We suggest that the desires to reside in 'new' and different places may be a way for students to enhance and diversify their cultural and mobility capital, and that this diversification is cultivated not only through international studies but might also extend post-study mobility as part of ongoing narratives of distinction throughout the life course. While our data does not allow us to discover whether students achieve their post-study aspirations, we argue that place represents 
future possibilities and the diverse ways that situated possibilities can develop into further mobility.

Finally, we conclude that place comparisons are a strategic narrative device used to highlight the differential value of places within global higher education and in the competition to valorise distinction. The preferential choice of, but also the recourse to, particular places for study underscores the differences in privilege and dis/advantage among international students. In other words, privileged students can afford (both economically and symbolically) to opt for an education in a place outside the reputability spectrum while students unable to afford or access education at reputable institutions may resort to emphasising 'place' and its features as a way to generate and compete for symbolic capital. Students' comparative narratives of places therefore highlight underlying tensions and conditions of privilege among international students whilst challenging the hegemonic symbolic value of institutional prestige as the only important signifier of difference, by reconfiguring distinction towards lifestyle and place-based qualities within a global higher education landscape.

Acknowledgements: The authors are very grateful to ESRC for funding this study under grant $\mathrm{ES} / \mathrm{k} 007394$. We wish to acknowledge the indispensable assistance a team of interviewers (Helen Packwood and Janis Paiders) who helped us in the UK, Austria and Latvia. 


\section{References}

Baláz, V. and Williams, A.M. (2004). 'Been There, Done That': International Student Migration and Human Capital Transfers from the UK to Slovakia. Population, Space and Place 10: 217-237.

Beech, S. (2014). Why place matters: imaginative geography and international student mobility Area 46(2): 170-177.

Beech, S. (2015). International student mobility: the role of social networks. Social \& Cultural Geography 16(3): 332-350.

Benson, M. and O'Reilly, K. (2009). Migration and the search for a better way of life: a critical exploration of lifestyle migration. The Sociological Review 57(4): 608-625.

Biao, X. and Shen, W. (2009). International student migration and social stratification in China. International Journal of Educational Development 29: 513-522.

Brooks, R. and Waters, J. (2009a). International higher education and the mobility of UK students. Journal of Research in International Education 8(2): 191-209.

Brooks, R. and Waters, J. (2009b). A Second Chance at 'Success': UK Students and Global Circuits of Higher Education. Sociology 43(6): 1085-1102.

Brooks, R. and Waters, J. (2010). Social networks and educational mobility: the experiences of UK students. Globalisation, Societies and Education 8(1): 143-157.

Brooks, R., Waters, J. and Pimlott-Wilson, H. (2012). International Education and the Employability of UK Students. British Educational Research Journal 38(2): 281-298.

Carlson, S. (2013). Becoming a Mobile Student - a Processual Perspective on German Degree Student Mobility. Population, Space and Place 19: 168-180.

Cohen, S.A., Duncan, T. and Thulemark, M. (2015). Lifestyle Mobilities: The Crossroads of Travel, Leisure and Migration. Mobilities 10(1): 155-172.

Collins, F.L., Sidhu, R., Lewis, N. and Yeoh, B.S.A (2014). Mobility and desire: international students and Asian regionalism in aspirational Singapore. Discourse: Studies in the Cultural Politics of Education 35(5): 661-676.

Collins, F. L. (2014). Globalising higher education in and through urban spaces: Higher education projects, international student mobilities and trans-local connections in Seoul. Asia Pacific Viewpoint 55(2): 242-257.

Collins, F.L., Ho, K.C., Ishikawa, M., and Ma, A.H.S. (2016). International Student Mobility and After-Study Lives: the Portability and Prospects of Overseas Education in Asia. Population, Space and Place. doi: 10.1002/psp.2029

Collins, F.L and Shubin, S. (2015). Migrant times beyond the lifecourse: The temporalities of foreign English teachers in South Korea. Geoforum 62: 96-104. 
Cuba, L., Hummon, D.M., 1993. Constructing a sense of home: place affiliation and migration across the life cycle. Sociology Forum 8 (4): 547-572.

Findlay, A.M., 2011. An assessment of supply and demand-side theorizations of international student mobility. International Migration 49 (2), 162-190.

Findlay, A.M., King, R., Stam, A. and Ruiz-Gelices, E. (2006). Ever Reluctant Europeans: The Changing Geographies of UK Students Studying and Working Abroad. European Urban and Regional Studies 13(4): 291-318.

Findlay, A.M., King, R., Smith, F., Geddes, A. and Skeldon, R. (2012). World class? An investigation of globalisation, difference and international student mobility. Transactions of the Institute of British Geographers 37(1): 118-131.

Findlay, A.M., Prazeres, L., McCollum, D. and Packwood, H. (2016). 'It was always the plan': international study as 'learning to migrate'. Area, doi:10.1111/area.12315

Geddie, K. (2013). The transnational ties that bind. Population, Space and Place, 19(2): 196208.

Gérard, M. and Uebelmesser, S. (2014). The Mobility of Students and the Highly Skilled: Implications for Education Financing and Economic Policy. Cambridge: MIT Press.

Ho, K.C. (2014). The university's place in Asian cities. Asia Pacific Viewpoint 55(2): 156-168.

Holloway, S.L., O'Hara, S. and Pimlott-Wilson, H. (2012). Educational mobility and the gendered geography of cultural capital: the case of international student flows between Central Asia and the UK. Environment and Planning A 44(9): 2278-2294.

King, R., Findlay, R., Ahrens, J. and Dunne, M. (2011). Reproducing advantage: the perspective of English school leavers on studying abroad. Globalisation, Societies and Education 9(2): 161-181.

Ma, S. A.-h. (2014). Social networks, cultural capital and attachment to the host city. Asia Pacific Viewpoint 55(2): 226-241.

Ministry for Education and Science (2016). http://www.izm.gov.lv/en/ministry

Mosneaga, A., and Winther, L. (2013). Emerging talents? International Students Before and After Their Career Start in Denmark, Population, Space and Place, 19(2): 181-195.

Murphy-Lejeune, E. (2002). Student Mobility and Narrative in Europe. London, Routledge.

OECD (2016) Education at a Glance. Paris: OECD

Phan, L.-H. (2016). Transnational Education Crossing 'the West' and 'Asia'. London, Routledge.

Raghuram, P. (2013). Theorising the Spaces of Student Migration. Population, Space and Place 19: $138-154$. 
Rizvi, F., 2005. International education and the production of cosmopolitan identities. In: Arimoto, A., Huan, F., Yokoyama, K. (Eds.), Globalization and Higher Education. Japan, Hiroshima University, Hiroshima, pp. 77-92.

Singh, J.K.N., Schapper, J., Jack, G., 2014. The Importance of place for international students' choice of university: a case study at a Malaysian university. Journal of Studies in International Education 18 (5), 463-474.

Shen, W. (2010). Globalizing Shanghai: International Migration and the Global City. Working Paper No. 79, World Institute for Development Economics Research.

Soon, J.-J. (2012). Home is Where the Heart Is? Factors Determining International Students' Destination Country upon Completion of Studies Abroad. Journal of Ethnic and Migration Studies 38(1): 147-162.

Tindal, S., Packwood, H., Findlay, A., Leahy, S. and McCollum, D. (2015). In what sense 'distinctive'? The search for distinction amongst crossborder student migrants in the UK. Geoforum 64: 90-99.

Waters, J. (2005). Transnational family strategies and education in the contemporary Chinese diaspora. Global Networks 5(4): 359-377.

Waters, J. (2006). Geographies of cultural capital: education, international migration and family strategies between Hong Kong and Canada. Transactions of the Institute of British Geographers 31(2): 179-192.

Waters, J. and Brooks, R. (2011). 'Vive la Différence?': The 'International' Experiences of UK Students Overseas. Population, Space and Place 17(5): 567-578.

Waters, J. (2012). Geographies of International Education: Mobilities and the Reproduction of Social (Dis)advantage. Geography Compass 6(3): 123-136

Waters, J., Brooks, R., Pimlott-Wilson, H., 2011. Youthful escapes? British students, overseas education and the pursuit of happiness. Social and Cultural Geography 12 (5): 455-469.

Yang, P. (2016). International Mobility and Educational Desire: Chinese Foreign Talent Students in Singapore. Palgrave, Basingstoke. 